\title{
The Possibility of Phase Change Materials (PCM) Usage to Increase Efficiency of the Photovoltaic Modules
}

\author{
Ewa Klugmann-Radziemska ${ }^{1}$, Patrycja Wcisło ${ }^{1, a}$, Michał Ryms ${ }^{1}$ and Hubert Denda ${ }^{1}$ \\ ${ }^{1}$ Gdansk University of Technology, Faculty of Chemistry, Gdansk 80-233, 11/12 Narutowicza, Poland
}

\begin{abstract}
Solar energy is widely available, free and inexhaustible. Furthermore this source of energy is the most friendly to the environment. For direct conversion of solar energy into useful forms like of electricity and thermal energy, respectively photovoltaic cells and solar collectors are being used. Forecast indicate that the first one solution will soon have a significant part in meeting the global energy demand. Therefore it is highly important to increase their efficiency in the terms of providing better energy conversion conditions. It can be obtain by designing new devices or by modifications of existing ones. This article presents general issues of photovoltaic installations exposed to work in high temperatures and basic concepts about phase change materials (PCMs). The paper presents the possibility of PCM usage to receive heat from the photovoltaic module. Specially designed test stand, consisting of PV module covered with a layer of PCM has been build and tested. Current-voltage characteristics of the cell without PCM material and with a layer of PCM have been presented. Authors also describe the results of the electrical and thermal characteristic of a coupled PV-PCM system.
\end{abstract}

\section{Introduction}

Photovoltaic modules can be combined with solar heat collectors to form hybrid energy generating units (PVT systems), that simultaneously produce low temperature heat and electricity. PVT systems have seen the intensive research and development activity last years

The operating temperature of a module is determined by the equilibrium between the heat produced by the PV module, the heat lost to the environment and the ambient operating temperature. The dominant temperature effect on silicon solar cell results in the overall decrease in the maximum output power of a solar cell or module as the temperature increases.

PV modules can lose up to $23 \%$ of its potential electric output power when the temperature increase is about $35 \mathrm{~K}$. Therefore, it is necessary to cool the modules in order to eliminate the negative effect of elevated temperature of PV module power output using the modules of silicon solar cells.

The semiconductor material most important physical properties that change with temperature are: the band gap, which decreases, and the minority-carrier lifetime, which increases with the temperature rise. The temperature increase causes also a significant build-in voltage drop, the potential barrier of the $p-n$ junction of the solar cell, and the separation ability of the junction as well [1].
There are many papers related PVT hybrid systems [2-5] and its applications in to BIPV systems [6-10].

Around the world $31.1 \mathrm{GW}$ of PV systems were installed in 2012, up from $30.4 \mathrm{GW}$ in 2011. PV remains, after hydro and wind power, the third most important renewable energy source in terms of globally installed capacity. 17.2 GW of PV capacity were connected to the grid in Europe in 2012, compared to $22.4 \mathrm{GW}$ in 2011 ; Europe still accounts for the predominant share of the global PV market, with 55\% of all new capacity in 2012 . For the second year in a row, PV was the number-one new source of electricity generation installed in Europe. Under a pessimistic Business-as-Usual scenario, the global annual market could reach $48 \mathrm{GW}$ in 2017 . Under a Policy-Driven scenario, it could be as high as $84 \mathrm{GW}$ in 2017 [11].

\section{Phase change materials (PCM) to modify PV panel}

Many techniques have been tested in order to improve the overall efficiency of photovoltaic panels. The most common were: anti-reflection coatings, radiation concentrators and ventilation. Some researchers have used cooling water as heat transfer material, however, such a solution on the long term proves to be quite expensive and liable to breaks due to leaks in such installations [12].

\footnotetext{
$\overline{{ }^{a} \text { Corresponding author: patrycja.wcislo@wp.pl }}$
} 
Promising materials to improve photovoltaic cells efficiency can be phase change materials, which are capable to stabilize photovoltaic cells temperature of PVT system in the range of $25-30^{\circ} \mathrm{C}$ [13].

Use PCMs have the ability to accumulate, store and release heat at a specific temperature called phase transition temperature. When the ambient temperature rise PCM accumulates and stores heat, and when the ambient temperature drops previously accumulated heat is released [10], [14].

\subsection{Classification of phase change material}

There are many substances capable to storage large amounts of heat during their phase transition and release the same amount of heat in the reverse direction. For pure substances the phase change occurs at the same temperature level and the melting and solidification process can be repeated for many cycles without change of phase change materials physicochemical properties [15].

Among phase change materials can be divided into: organic compounds (e.g.: waxes, paraffins, fatty acids, alcohols), inorganic compounds (hydrated salts) and eutectic mixtures [16]. These compounds have different phase change temperature ranges which together with the proper melting point temperature, determines their usability in specified applications. For example, suitable paraffin can be used to stabilize the temperature of working PV cell by the absorption of the excess heat during melting process [17], [18]. There are commercially available phase change materials to the proper applications. These materials are being offered by Rubitherm and BASF companies. A classification of PCMs is given in Fig. 1.

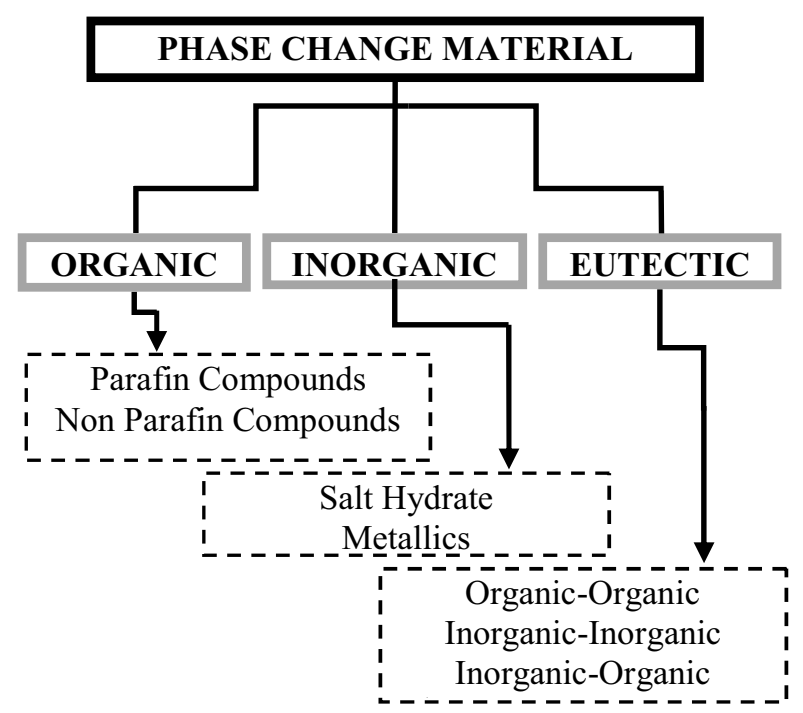

Figure 1. Classification of PCMs [27].

\subsection{Properties of PCMs}

PCMs belonging to the macromolecular hydrocarbons (paraffins and waxes) may find their application as heat storages from PV modules.

This compounds have many good advantages using as phase change materials, such as:

- high thermal capacity,

- non-toxic / safety,

- chemically neutral,

- reliability,

- non-corrosive,

- low price (cost) [19].

However, organic phase change materials have also some drawbacks e.g.:

- low thermal conductivity $\sim 0,2 \mathrm{~W} / \mathrm{mK}$,

- wide range of melting temperatures,

- pure paraffin waxes are very expensive (only technical grade paraffins can be used) [20],

- low volumetric latent heat storage capacity,

- $\quad$ flammable [21].

\section{Photovoltaic}

Photovoltaic is one of the most environmentally friendly technology which allows production of electricity from renewable energy sources. Radiant energy of sunlight is converted directly into electrical energy [12].

In recent years, interest in photovoltaic has increased much, not only because of the ability to generate large amounts of electricity, but also because of the possibility of using widely available renewable energy sources. Photovoltaic panels are the source of clean energy, because during its production is not emitted carbon dioxide and other harmful gases into the atmosphere. PV panels allow use of widely available and free energy source. Furthermore use of this technology allows to reduce production of non-renewable fossil fuels such as carbon or petroleum.

\subsection{Photovoltaic panels}

PV panels consist of modules, and these in turn of photovoltaic cells. Basically, the module is composed of 36-72 cells that are connected in series or in parallel. The principle of operation is based on photovoltaic solar radiation absorption by the semiconductor resulting in the formation of electrical charge carriers and it is possible to flow electric current in the external circuit.

When designing the installation of PV systems must take into account:

- the intensity of solar radiation,

- the angle incidence of solar radiation on the PV panels,

- pressure,

- density,

- air pollution.

Optimum angle is when the rays of a sunny fall perpendicularly on the plane PV module. Then the modules receives the most sunlight. Therefore often used periodically change the angle PV [1]. 
Solar cells and solar panels work best at certain temperatures, according to their material properties (for silicon cells is about $25^{\circ} \mathrm{C}$ ) [12].

With the increase in cell temperature the following effects are observed:

- the voltage of the system decreases,

- the short-circuit current increases,

- $\quad$ electric power decreases [22].

To compare the performance of different solar power modules uniform operating data have been defined as Standard Test Conditions (STC). By using a fixed set of conditions, all solar panels can be more accurately compared and rated against each other. There are three standard test conditions which are: temperature of the cell: $25^{\circ} \mathrm{C}$; Solar Irradiance: 1000 Watts per square meter, mass of the air AM=1.5 (it refers to the amount of light that has to pass through Earth's atmosphere before it can hit Earth's surface, and has to do mostly with the angle of the sun relative to a reference point on the earth; AM is minimized when the sun is directly above as the light has to travel a minimum distance straight down, and increases as the sun goes farther from the reference point and has to go at an angle to hit the same spot).

\section{Solar PV resources}

The global solar resource is massive. Around 885 million TWh worth of solar radiation reaches the Earth's surface each year [23]. Figure 2 presents the local solar resource for Poland, expressed as yearly sum of global horizontal irradiation.

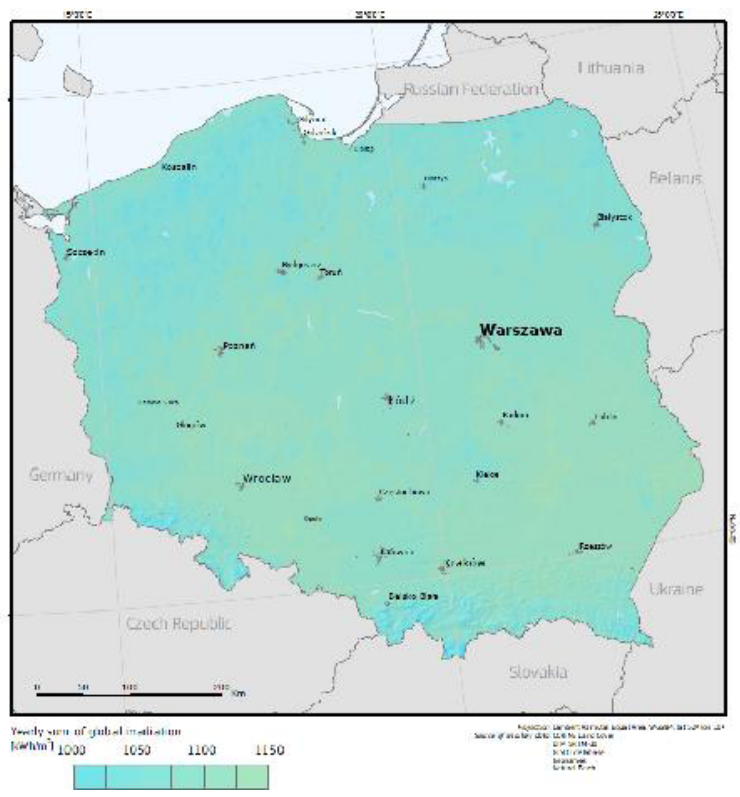

Figure 2. Yearly sum of global irradiation for horizontal surface [24]

Global Horizontal Irradiation (GHI) is the total amount of shortwave radiation received from above by a horizontal surface. This is expressed as W/m2 and includes both direct normal irradiance (DNI) and diffuse horizontal irradiance (DIF). In Europe, the average solar resource is a round $1200 \mathrm{kWh} / \mathrm{m} 2 /$ year, while in the Middle East it typically varies between 1800 and $2300 \mathrm{kWh} / \mathrm{m}^{2}$ year. However, using tilting modules can increase the irradiance (per unit of surface area) by up to $35 \%$ (500 $\mathrm{kWh} / \mathrm{m}^{2}$ year), especially for latitudes lower than $30^{\circ} \mathrm{S}$ and higher than $30^{\circ} \mathrm{N}$ [25]. Tracking can also increase the yield, but with considerable additional expense.

\section{Theoretical consideration}

Over $80 \%$ of the world solar cell and module production is currently based on sliced single crystal and polycrystalline silicon cells, so this paper is focused on the silicon modules.

The photovoltaic efficiency of solar cells is temperature dependent and it decreases with the increasing temperature due to the worse mobility of carriers, diffusion length and lifetime of minority carriers and saturation current.

Standard test conditions (STC) occur very rarely. Temperature of the module (cells) can rise much more above $S T C$, causing a power and efficiency drop of crystalline silicon PV module with a coefficient of -0.4 to $-0.65 \% / \mathrm{K}$ above $S T C$ temperature. At normal and lower temperatures, $298 \mathrm{~K}$, silicon is a good material, but at high temperatures, $200^{\circ} \mathrm{C}$ for instance, silicon efficiency dropped to $5 \%$.

Due to the absorption of electromagnetic radiation also the heat is produced by a solar module. Apart from heating, radiation entering a solar cell can set free electrons from its atomic bond creating electron - hole pairs. In order to generate the electron-hole pair, the sufficient photon energy must be provident to the cell, at least equal to the material band-gap energy. Then, by means of a built-in potential barrier of the p-n junction the electrons are separated from holes, generating a photoelectric current, Joule's heat in the series resistance of the module and electric power in the load circuit as well. A temperature increase above $25^{\circ} \mathrm{C}$ degrades significantly $V_{o c}$ and output power and conversion efficiency of a silicon solar module (often power loss is equal to $0.5 \% / \mathrm{K}$ ) [26]. In order to diminish this effect, it is useful to decrease the module temperature by removing the heat.

The temperature dependence of the solar-cell opencircuit voltage $\left(V_{o c}\right)$ is given by [27]:

$$
V_{o c}(T)=V_{o c}\left(T_{0}\right)-\left[\frac{\varepsilon_{g o b}}{\varepsilon}-V_{o c}\left(T_{0}\right)\right]\left[\frac{T}{T_{a}}-1\right]-\frac{3 h T}{g} \ln \frac{T}{T_{1}}
$$

where: $e$ - elementary charge $(\mathrm{C}), T$ - temperature $(\mathrm{K}), E_{g}$ - band gap $(\mathrm{eV}), k$ - Boltzmann's constant $(\mathrm{J} / \mathrm{K})$.

During the work of a solar cell, if the temperature rises e.g. by $40 \mathrm{~K}$, in case of $T_{0}=300 \mathrm{~K}$ and $T=340 \mathrm{~K}$ : $\ln \frac{T}{T_{w}} \cong 0.125$ and $\frac{3 h T}{G} \ln \frac{T}{T_{\omega}} \cong 10 \mathrm{mV}$ can be neglected.

Thus, we get from Eq. (1) an approximately linear function:

$$
V_{o c}(T)=V_{o c}(300 K)-\text { const }(T-300 K)
$$


The change of $V_{o c}$ with temperature as calculated from Eq. (1) is:

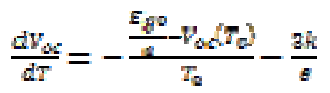

In case of $T_{0}=300 \mathrm{~K}, E_{g 0}=1.21 \mathrm{eV}$ and $V_{o c}\left(T_{0}\right)=0.55 \mathrm{~V}$, typical for a silicon solar cell, we get from (6) the decrease $V_{o c}$ with the increasing temperature of $\frac{d V_{Q C}}{d T}=-2.45 \frac{m V}{R}$ or about $-0.4 \frac{\%}{R}$, measured relative to $V_{o c}$ at $25^{\circ} \mathrm{C}$ [4].

This value is also in agreement with Green [28].

The electrical efficiency $\eta_{e l}$ is given as a function of temperature:

$$
\eta_{e l}=\eta_{0}\left[1-\beta\left(T_{E s l l}-298 K\right)\right]
$$

with $\eta_{0}$ - efficiency of the module at temperature of 298 $\mathrm{K}$.

Silicon efficiency temperature coefficient: $\beta=-4.5 \cdot 10^{-3}{ }_{K} \quad[5], \quad \beta=-6.6 \cdot 10^{-3} K \quad[2] \quad$ or $\beta=-6.4-10^{-3} K[3]$.

\section{Experiment}

Solar cells and solar panels work best at certain temperature, according to their material properties. Experimental studies were conducted with the use of $\mathrm{PV} / \mathrm{PCM}$ system, consisting of crystalline silicon module with the layer of phase change material. The aim of the PCM use is to stabilize the module temperature on the optimal level of $22-23^{\circ} \mathrm{C}$.

\subsection{Materials and methods}

The authors modified two different photovoltaic modules that were used the test stands. One of them was "Solarwatt", module type ASE-100-DGL-SM (Module 1), while the second was "GreenTech SOLAR ENERGY", module type GT-70PBX (Module 2). The parameters of the modules was shown in Table 1. (all technical data at standard test conditions: $\mathrm{AM}=1.5$; $\left.\mathrm{E}=1000 \mathrm{~W} / \mathrm{m}^{2} ; \mathrm{Tc}=25^{\circ} \mathrm{C}\right)$.

Table 1. The parameters of modules.

\begin{tabular}{|c|c|c|}
\hline Module type & $\begin{array}{c}\text { GT- } \\
\text { 70PBX }\end{array}$ & $\begin{array}{c}\text { ASE-100- } \\
\text { DGL-SM }\end{array}$ \\
\hline $\begin{array}{c}\text { Peak Power }\left(\mathrm{P}_{\max }\right)[\mathrm{W}] \\
\text { Maximum Power Current (Imp) } \\
{[\mathrm{A}]}\end{array}$ & 70 & 95 \\
\hline $\begin{array}{c}\text { Maximum Power Voltage (Vmp) } \\
{[\mathrm{V}]}\end{array}$ & 4.09 & 2.7 \\
\hline $\begin{array}{c}\text { Short Circuit Current }\left(\mathrm{I}_{\mathrm{SC}}\right)[\mathrm{A}] \\
\text { Open Circuit Voltage }\left(\mathrm{V}_{\mathrm{OC}}\right)[\mathrm{V}]\end{array}$ & 21.63 & 35 \\
\hline & 2.13 & 2.75 \\
\hline
\end{tabular}

The Module 1 with an area equal $0.75 \mathrm{~m}^{2}$ consists 72 single cells. This photovoltaic module was modified by applying a single PCM layer of RUBITHERM RT22 material $(0.01 \mathrm{~m})$. Module 2 with an area equal to $0.53 \mathrm{~m}^{2}$ consists 36 single cells. Module 2 was modified by applying a single PCM layer of Ceresine $(0.015 \mathrm{~m})$ from Petroleum Industry. The thermal analysis were carried out on a Differential Scanning Calorimeter TA Q20. PCM RT22 and Ceresine properties, in the form of heat flow diagrams, have been determined. Analysis were conducted in the temperature range between 5 and $40^{\circ} \mathrm{C}$ (PCM RT 22) and between 5 and $90^{\circ} \mathrm{C}$ (Ceresine). Researches obtained the typical properties of phase change materials: enthalpy, the specific heat, the phase transition temperature, heat flux, etc. Thermophysical properties of PCM RT22 and Ceresine are presented in Table 2. The DSC diagram for RT22 and Ceresine are shown in the Figure 3 and for Figure 4 respectively.

Table 2. Thermophysical parameters of Phase Change Material RT22 from RUBITHERM and Ceresine

\begin{tabular}{|c|c|c|}
\hline Parameter & RT22 & Ceresine \\
\hline melting point $\left(\mathrm{t}_{\mathrm{m}}\right)$ & $20-23^{\circ} \mathrm{C}$ & $61-78^{\circ} \mathrm{C}$ \\
\hline density $(\rho)$ & $0.76\left[\mathrm{~kg} / \mathrm{m}^{3}\right]$ & $0.91\left[\mathrm{~kg} / \mathrm{m}^{3}\right]$ \\
\hline specific heat for $\left(\mathrm{c}_{\mathrm{p}}\right)$ & $2[\mathrm{~kJ} / \mathrm{kg} \cdot \mathrm{K}]$ & $2.9[\mathrm{~kJ} / \mathrm{kg} \cdot \mathrm{K}]$ \\
\hline enthalpy $(\mathrm{h})$ & $200[\mathrm{~kJ} / \mathrm{kg}]$ & $160[\mathrm{kgJ} / \mathrm{kg}]$ \\
\hline thermal conductivity $[\lambda]$ & $0.2[\mathrm{~W} / \mathrm{m} \cdot \mathrm{K}]$ & $0.25[\mathrm{~W} / \mathrm{m} \cdot \mathrm{K}]$ \\
\hline
\end{tabular}

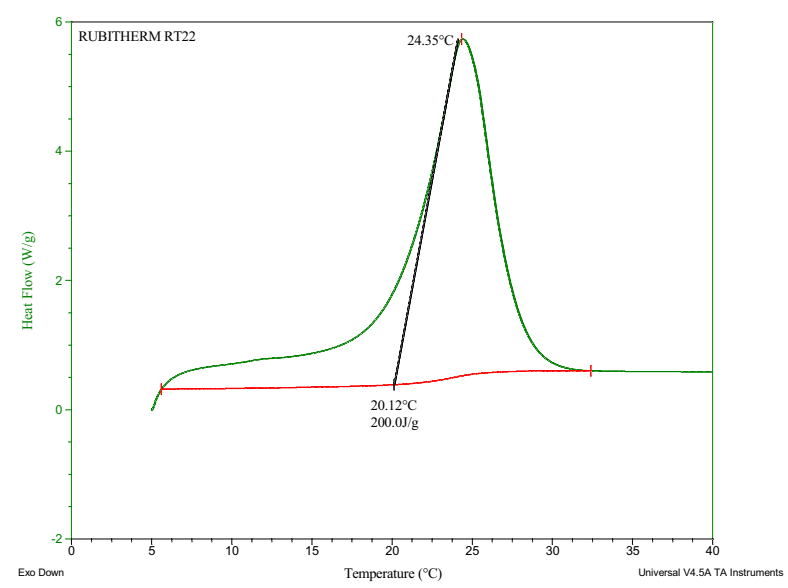

Figure 3. DSC curves obtained from a thermal cycle between $5^{\circ} \mathrm{C}$ and $40^{\circ} \mathrm{C}$ for PCM RT 22 from RUBITHERM.

The experiment was carried out under natural sunlight light with irradiance in the range of $400 \div 1000 \mathrm{~W} / \mathrm{m}^{2}$ in Gdansk at the beginning of April. The intensity of radiation $\left[\mathrm{W} / \mathrm{m}^{2}\right]$ was measured by Kipp \& Zonen pyranometer SP LITE-2. The authors examined the photovoltaic modules (Module 1 and Module 2) without layer of PCMs, and after modification by covering it with by covering it with a PCM material layer with a thickness of $0.01 \mathrm{~m}$ (Module 1) and $0.015 \mathrm{~m}$ (Module2). Schematic view of the experimental stand is shown in the Figure 5. 


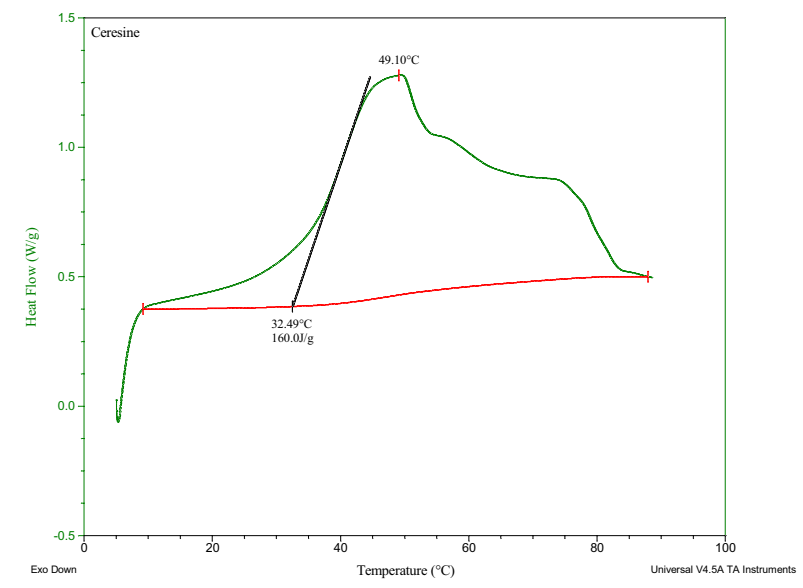

Figure 4. DSC curves obtained from a thermal cycle between $5^{\circ} \mathrm{C}$ and $90^{\circ} \mathrm{C}$ for Ceresine.

To reduce the temperature of the PV module the layer of proper PCM material with the thermophysical parameters defined in Table 2 and the thickness 0.01 [m] (Module 1) and $0.015 \mathrm{~m}$ (Module 2) was applied on the rear surface of the modules (Figure 6).

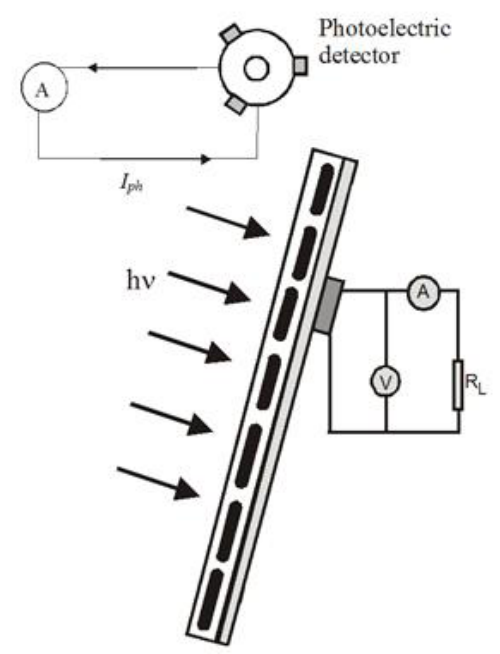

Figure 5. Schematic diagram of the experimental stand for current-voltage characteristics determination.

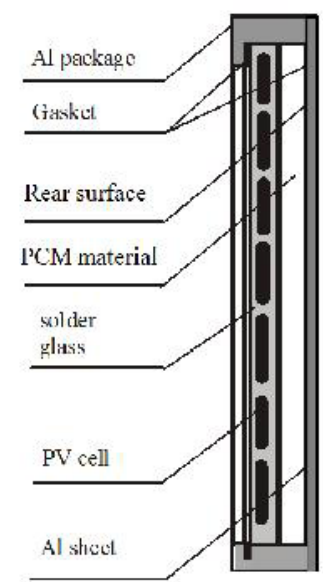

Figure 6. The construction of tested PV/PCM system.

\subsection{Result and discussion}

The characteristics of the current-voltage of photovoltaic module modified and unmodified with the PCM layer was measured. Figure 7 and 8 show the current-voltage characteristic under irradiation of $1045 \mathrm{~W} / \mathrm{m}^{2}\left(\mathrm{t}_{\mathrm{amb}} 23^{\circ} \mathrm{C}\right)$. Temperature of the modules, measured with the use thermovision camera Fluke type TiR 3. This device allowed for remote and non-contact measurement of temperature distribution of PV module. The measurements were performed at $1 \div 2 \mathrm{~m}$ from the test object. Thermograms was carried out using SmartView program. Thermograms of PV modules are shown in Figure 9 and 10.

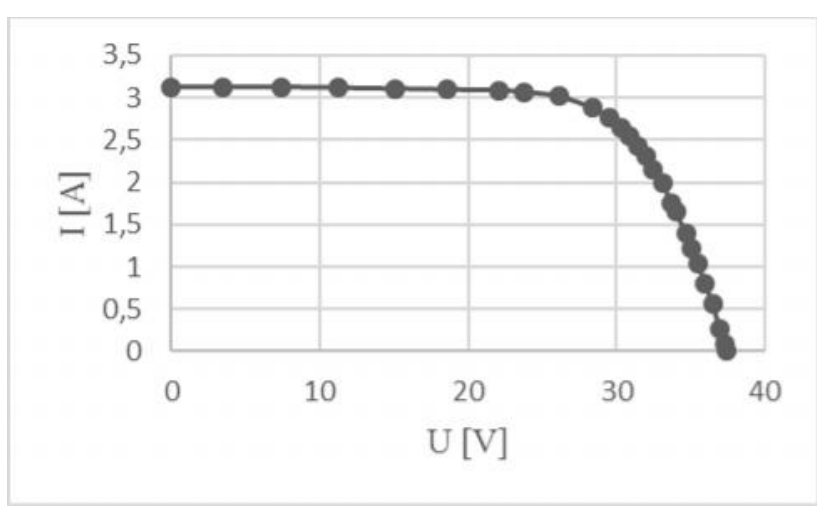

Figure 7. Current-Voltage characteristic under $1045 \mathrm{~W} / \mathrm{m}^{2}$ with the temperature of the module $60^{\circ} \mathrm{C}$ (without $\mathrm{PCM}$ ) for Module 1.

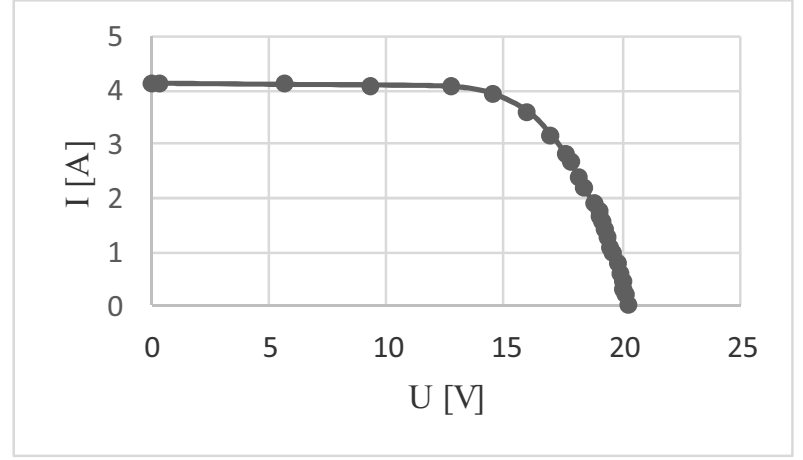

Figure 8. Current-Voltage characteristic under $1045 \mathrm{~W} / \mathrm{m}^{2}$ with the temperature of the module $60^{\circ} \mathrm{C}$ (without $\mathrm{PCM}$ ) for Module 2.

When the module temperature increased to 55 degrees Centigrade, the efficiency of the cells decreased by $15 \%$ of its STC efficiency. 


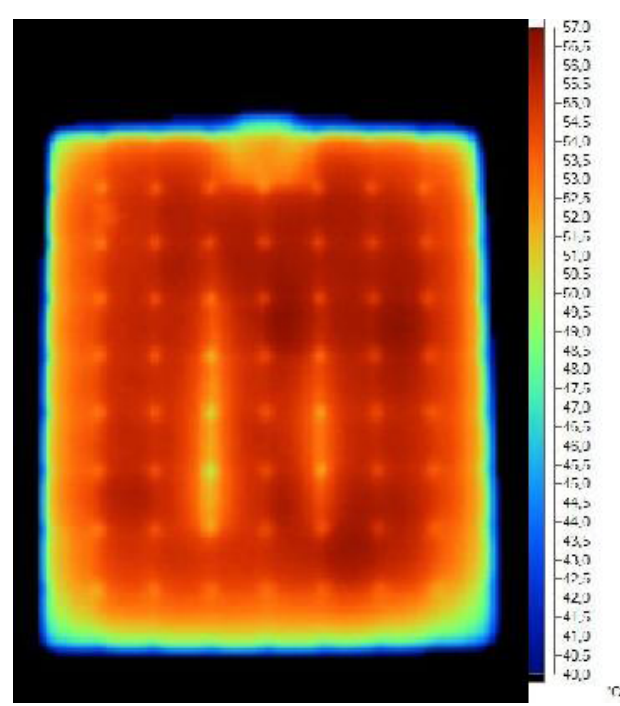

Figure 9. Thermovision image of PV module (Module 1).

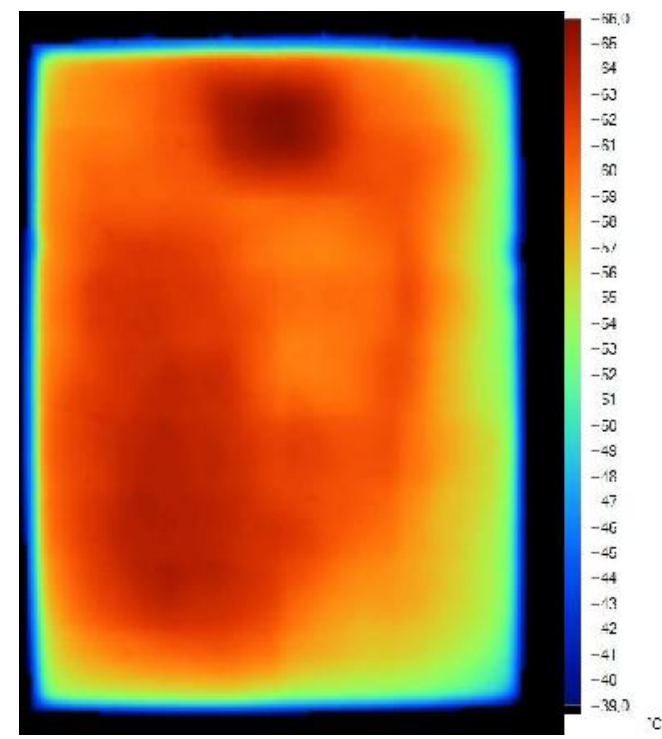

Figure 10. Thermovision image of PV module (Module 2).

The elevation of the irradiance causes the increase of the PV module electric power, but at the same time the increased module temperature causes a decrease in the PV efficiency. Determination of the maximum power point of a PV module in particular lighting conditions and temperature gives the possibility for the best module operation conditions optimization. At very high intensity sunlight short-circuit current of PV module increases and couse the rise of electrical power and - consequently comes to the position of the maximum power point on the current - voltage characteristic shift. Open circuit voltage of the PV module decreases with increasing temperature while the short-circuit current value remains nearly unchanged. Consequently, it comes to reduction in electrical power and the position of the maximum power point on the current - voltage characteristic. Therefore cooling of the module is important and can reduce its working temperature in order to increase the efficiency of photovoltaic conversion.

\section{Conclusions}

Experimental studies were performed on PV silicon crystalline modules. Use of the PV/PCM system, where the PV module is cooled by PCM material, allows to improve electrical parameters of the loaded modules.

Optimum operating temperature is stabilized by phase change materials. The allocation of a proper mass of PCM on the rear part of a traditional PV module contributes to lower its operative temperature, thus improving the overall energy conversion efficiency of the module. This work presents the first results of an experimental study of the thermal behavior of an integrated PV/PCM module.

Calculated on the base of experimental results calculated module efficiency was equal to $10.5 \%$ (Module 1), $10.15 \%$ (Module 2) for a modified modules and $10.8 \%$ (Module 1), $10.6 \%$ (Module 2) for a modules without PCM material layer in this same conditions. We found out that the temperature of both modules (modified and unmodified a layer of PCM material) is nearly the same and it is equal about $55^{\circ} \mathrm{C}$ - the desired effect of PV module cooling was not achieved. It could be caused by using too thin layer of PCM material or improper selection of PCM material. In the future, authors are going to use thicker layers and other PCM materials, especially mixtures of different paraffin.

\section{References}

1. E. Klugmann-Radziemska, Fotowoltaika $w$ teorii $i$ praktyce (Wydawnictwo BTC, Legionowo 2010).

2. E. Radziemska, Renew. Energy, 28, 1-12 (2003).

3. Y. Tripanagnostopoulos, T.H. Nousia, M. Souliotis, P. Yianoulis, Sol. Energy 72/3, 217 (2002).

4. E. Radziemska, E. Klugmann, Energy Conv. Management, 43, 1889 (2002).

5. H.A. Zondag at al., Sol. Energy, 72/2, 113 (2002).

6. B. Norton, P.C. Eames, T.K. Mallick, M.J. Huang, S.J. McCormack, J.D. Mondol, Y.G. Yohanis, Sol. Eng., 85 (8), 1629-1664 (2011).

7. I. Adnan, Y.O. Mohd, H.R. Mohd, M. Sohif, K. Sopian, Renew. Sustain. Energy Rev., 15, 352-365 (2011).

8. A. Hasan, S.J. McCormack, M.J. Huang, B. Norton, Sol. Energy, 84 (9), 160-1612 (2010).

9. P.G. Charalambous, G.G. Maidment, S.A. Kalogriou and K. Yiakoumetti, Appl. Therm. Eng., 27, 275286 (2007).

10. P. Lamberg, R. Lehtinemi and A. M. Henell, Int. J. Therm. Sci., 43 (3), 277-287 (2004).

11. G. Masson, M. Latour, M. Rekinger, I.T. Theologitis, M. Papoutsi, Global Market Outlook for Photovoltaics 2013-2017, (EPIA 2013).

12. E. Radziemska and E. Klugmann, Przegl. Elektrotech., 4, 291-295 (2003).

13. C. S. Malvi, D. W. Dixon-Hardy, and R. Crook, Sol. Energy, 85, 1440-1446 (2011).

14. A. Melcer, E. Klugmann-Radziemska, and W. Lewandowski, Przem. Chem., 7, 1000-1011 (2012). 
15. M. Cellura, G. Ciulla, V. Lo Brano and A. Marvuglia, Conference on Passive and Low energy Architecture, October, 22-27, Dublin 2008.

16. M. Kenisarin and K. Mahkamov, Renev. Sustain. Energy Rev., 11, 1913-1965 (2007).

17. M. J. Huang, P. C. Eames, and B. Norton, Int. J. Heat Mass Transf., 47, 2715-2733 (2004).

18. M. J. Huang, P. C. Eames, and B. Norton, Sol. Energy, 80, 1121-1130 (2006).

19. A. Sharma, V. V. Tyagi, C. R. Chen, and D. Buddhi, Renew. Sustain. Energy Rev. 13, 318-345 (2009).

20. M. M. Farid, A. M. Khudhair, S. A. K. Razack, and S. Al-Hallaj, Energy Convers. Manag., 45, 15971615 (2004).

21. F. Kuznik, D. David, K. Johannes, and J.-J. Roux, Renew. Sustain. Energy Rev., 15, 379-391 (2011).

22. E. Radziemska, P. Ostrowski, and P.-P. Katarzyna, Proc. ECOpole, 2, 461-466 (2008).

23. IEA, Sol. Energy Perspectives, IEA/OECD, Paris (2011)

24. Súri M., Huld T.A., Dunlop E.D. Ossenbrink H.A., Sol. Energy, 81, 1295-1305 (2007), http://re.jrc.ec.europa.eu/pvgis/.

25. Cost Analysis of Solar Photovoltaics (2012), Renewable Energy Technologies, International Renewable Energy Agency, Germany.

26. E. Radziemska, Performance Analysis of a Photovoltaic-Thermal Integrated System, International Journal of Photoenergy Hindawi Publishing Corporation 2009, doi:10.1155/2009/732093.

27. D. Carlson, Low-cost power from thin-film PV, in: Electricity, Ed. Lund University Press, Lund (1989).

28. M.A. Green Solar, Cells, University of New South Wales, Kensington, 1992. 